\title{
Operation of fitness centers during the COVID-19 pandemic: opinions of Brazilian managers
}

\author{
Vinícius Nagy Soares ${ }^{1}$ \\ Paula Teixeira Fernandes²
}

\section{$\underline{\text { ABSTRACT }}$}

The new coronavirus disease (COVID-19) has impacted sports-related professionals. Brazilian fitness centers remained closed between March and July, resulting in a large number of professionals being dismissed. Although our country is still far from overcoming COVID-19, fitness centers are back in operation. In this study, we interviewed gym managers to understand the socioeconomic effects of the pandemic and identify strategies to reduce the chances of SARS-CoV-2 transmission. We considered 85 responses via a Google Forms questionnaire and identified that disinfection of the environment and availability of $70 \%$ alcohol were in consensus.

There was also agreement on social distancing, mask use, and temperature assessment. Our main concern relates to social distancing, which seems unfeasible in environments focused on sports practice. We believe that these measures may difficult virus circulation, but may be insufficient to prevent SARS-CoV-2 infection. Finally, the measures imposed by Brazilian state governors to restrict opening hours may worsen the implementation of social distancing in fitness centers.

Indexing Terms: Epidemiology, Pandemics, Coronavirus Infections, Physical Exercise.

${ }^{1}$ Graduate Program in Gerontology, Faculty of Medical Sciences. Group of Studies in Sport Psychology and Neurosciences (GEPEN) State University of Campinas, Cidade Universitária Zeferino Vaz - Barão Geraldo, Campinas, SP, Brazil. Correspondência para: VN Soares. E-mail: <viniciusnagy@gmail.com>

${ }^{2}$ Graduate Program in Gerontology, Faculty of Medical Sciences. State University of Campinas, Department of Sports Sciences, Faculty of Physical Education. Group of Studies in Sport Psychology and Neurosciences (GEPEN) State University of Campinas. Campinas, SP, Brazil

Como citar este artigo / How to cite this article

Soares VN, Fernandes PT. Operation of fitness centers during the COVID-19 pandemic: opinions of Brazilian managers. InterAm J Med Health 2021;4:e202101018. 


\section{MANUSCRIPT TEXT}

The new coronavirus disease (COVID-19) has changed the lives of people around the world. Strategies such as social distancing, large-scale diagnosis, and tracking of SARS-CoV-2 transmission chains have been adopted in most countries and have proven effective in controlling the outbreak of COVID-19 [1]. In the last year, socio-environmental interactions were drastically modified, causing people to stay at home longer. In this sense, Google's mobility reports showed that inhabitants reduced the frequency of occupancy of different categories of places, such as retail and recreation, grocery and pharmacy, parks, transit stations, and workplaces [2].

In Brazil, a government decision in early March determined that only essential activities could operate in the most severe phases of COVID-19. Consequently, the economic projections that were ruinous before the pandemic, became even worse after the reduction of commercial activity. But this outcome was not a Brazilian particularity. According to International Monetary Fund (IMF), most countries may had a recession in 2020, and probably, in 2021, with significant declines in Gross Domestic Product (GDP) [3].

The paralysis of different economic sectors has caused tensions between social classes, encouraging many employees to return to work. The dichotomy between "health" and "economy" has become increasingly frequent in society, reinforcing the pressures for return to "normality". In response to this, Brazilian Federal Government expanded the group of essential activities, allowing the operation of fitness centers, according to Decree No. 10,344 of May 8, 2020 [4].

A recent review shown that physical exercise increases immune response against infectious agents, which could be important especially at this time [5]. Thus, there is no doubt that fitness centers are fundamental for the promotion of health. However, the release of fitness centers opposes the policies of social distancing recommended by the World Health Organization (WHO) [6], because the practice of physical exercises in indoor environments can increase the chances of dissemination of SARS-CoV-2. In this sense, a South Korean study found 112 cases of COVID-19 related to fitness dance classes [7]. The cluster analysis revealed that half of infections occurred from instructor to participant, who started to feel respiratory symptoms approximately three days after fitness dance [7].

Brazil is currently in the worst phase of the pandemic, with its public health system close to collapse. Against this background, we interviewed gym managers to understand the socioeconomic effects of the pandemic and identify strategies to reduce the chances of SARSCoV-2 transmission.

This is a descriptive study conducted through an online questionnaire. We interviewed managers of regulated gyms that provided services in sports such as weight training, gymnastics, dance, fights, functional training, Crossfit or team sports. The interviews were conducted between late July and early August 2020. The divulgation of this study happened through social media, where those interested were invited to access a link to the virtual questionnaire. The questionnaire approached aspects such as characteristics of fitness centers, perception of epidemiological aspects and operation protocol. The responses were exported to spreadsheet and presented using descriptive statistics. This study was approved by the Ethics Committee of the State University of Campinas, São Paulo, Brazil (CAAE: 33472120.1.0000.5404).

We received 96 responses, but 11 duplicates were excluded. In some cases, repeated answers were because the participant managed more than one fitness center. The fitness centers were located in the State of São Paulo (55.3\%), Minas Gerais (17.6\%), Bahia (11.8\%), Rio de Janeiro (3.5\%), Ceará (3.5\%), Paraná (2.4\%), Rio Grande do Sul (2.4\%), Espírito Santo (1.2\%), Pará (1.2\%) and Pernambuco (1.2\%). On average, the fitness centers had been working for $11 \pm 9$ years, had approximately $12 \pm 11$ employees and $516 \pm 791$ frequenters. The fitness classes were predominantly indoor (80\%), with temperature control by fans $(52.9 \%)$, air conditioning $(24.7 \%)$ and both $(22.4 \%)$. Regarding the perception of economic profile of frequenters, the interviewees provided services predominantly for social classes C (47.5\%) and B (41.5\%).

Table 1 presents the perception of managers of fitness centers about COVID-19. Most managers classified the severity of the disease as high or moderate. The social distancing was well accepted, but approximately half of the sample believed that only the most vulnerable people should be isolated. Scientific articles and social media were the vehicles of communication that most influenced opinions of respondents. 
Table 1. Perceptions of fitness center managers about COVID-19.

\begin{tabular}{|c|c|c|}
\hline Questions & N & $\%$ \\
\hline How do you classify the gravity of COVID-19? & & \\
\hline Hoderate & 43 & 51.2 \\
\hline Low & 36 & 42.9 \\
\hline Yes & 5 & 6.0 \\
\hline Do you agree with the social distancing? & 65 & 76.5 \\
\hline People? & & \\
\hline Yes & 41 & 48.2 \\
\hline Do you believe that social distancing should occur only among vulnerable \\
\hline Scientific articles & 68 & 80.0 \\
\hline Television & 38 & 44.7 \\
\hline YouTube & 35 & 41.2 \\
\hline Social medias (Facebook, Instagram, Twitter, WhatsApp) & 32 & 37.6 \\
\hline Newspaper & 20 & 23.5 \\
\hline
\end{tabular}

Table 2 presents economic aspects of fitness centers and consequences caused by inactivity between March and July/August 2020. We observed that most managers paid rent, but there was understanding from owners, who offered discounts during the period of inactivity. Approximately half of the fitness centers received financial support from Brazilian government, but few managers were satisfied with the amount received. Two out of three managers had to dismiss employees, in which around five workers per gym were dismissed during the pandemic. Managers who had not yet dismissed their employees would have to dismiss if the gym remained closed for another month. 
Table 2. Economic aspects of fitness centers

\begin{tabular}{|c|c|c|}
\hline Questions & N & $\%$ \\
\hline Does the gym pay rent? & & \\
\hline Yes & 63 & 74.1 \\
\hline Was there a discount during the pandemic? & 48 & 77.4 \\
\hline Yes & & \\
\hline Yes & 40 & 47.1 \\
\hline Did you get financial support from the government? & & \\
\hline How do you rate the support received? & 16 & 40.0 \\
\hline Insufficient & 19 & 47.5 \\
\hline Regular & 5 & 12.5 \\
\hline Adequate & 5.5 & 3.4 \\
\hline Yid you have to dismiss employees? & 55 & 22.5 \\
\hline
\end{tabular}

SD $=$ Standard deviation

Table 3 shows the measures that managers were adopting to prevent the transmission of SARS-CoV- 2 in sports environments. Some conducts were consensual, such as disinfection of the environment and availability of $70 \%$ alcohol. Most fitness centers will not allow older adults and people without masks in sports environments. The majority will adopt social distancing in sports environments, whose reported method was to mark the floor to maintain a minimum distance of 2 meters between frequenters. Distances of 1.5, 2.5 and 3.0 meters were few mentioned. Other conducts such as scheduling and temperature measurement will also be adopted by most managers. 
Table 2. Economic aspects of fitness centers

\begin{tabular}{|c|c|c|}
\hline Questions & $\mathbf{N}$ & $\%$ \\
\hline \multicolumn{3}{|l|}{ Did your employees receive any training about COVID-19? } \\
\hline Yes & 63 & 74.1 \\
\hline \multicolumn{3}{|l|}{ Will older adults be able to go to the sports environment? } \\
\hline No & 48 & 77.4 \\
\hline \multicolumn{3}{|l|}{ Do you consider it important to disinfect the sports environment? } \\
\hline Yes & 40 & 47.1 \\
\hline \multicolumn{3}{|l|}{ The disinfection of sports environment will be: } \\
\hline Periodic & 16 & 40.0 \\
\hline After use & 19 & 47.5 \\
\hline Who will disinfect the sports environment? & 5 & 12.5 \\
\hline \multicolumn{3}{|l|}{ Frequenters and employees } \\
\hline Employees only & 55 & 64.7 \\
\hline Frequenters only & 5.5 & 3.4 \\
\hline Will you provide $70 \%$ alcohol at the sports environment? & 24.0 & 22.5 \\
\hline \multicolumn{3}{|l|}{ Yes } \\
\hline \multicolumn{3}{|l|}{ Will classes be scheduled? } \\
\hline \multicolumn{3}{|l|}{ Yes } \\
\hline \multicolumn{3}{|l|}{ Will you recommend social distancing in the sports environment? } \\
\hline \multicolumn{3}{|l|}{ Yes } \\
\hline \multicolumn{3}{|c|}{ Do you believe it is feasible to practice social distancing in the sports environment? } \\
\hline \multicolumn{3}{|l|}{ Yes } \\
\hline \multicolumn{3}{|l|}{ Will you provide personal protective equipment to employees? } \\
\hline \multicolumn{3}{|l|}{ Yes } \\
\hline \multicolumn{3}{|l|}{ Can professionals without a mask work? } \\
\hline \multicolumn{3}{|l|}{ No } \\
\hline \multicolumn{3}{|l|}{ Can frequenters without a mask practice physical exercise? } \\
\hline \multicolumn{3}{|l|}{ No } \\
\hline \multicolumn{3}{|l|}{ Will you check the temperature of the frequenters? } \\
\hline \multicolumn{3}{|l|}{ Yes } \\
\hline \multicolumn{3}{|l|}{ Do you believe there will be infection in the sports environment? } \\
\hline No & & \\
\hline
\end{tabular}


Finally, most managers (82.4\%) said that the costs of these measures would not be passed on to users.

As the results suggest, the COVID-19 pandemic affected Brazilian fitness centers. The period of inactivity resulted in many employees dismissed due to economic decline in recent months. The difficulty in receiving financial support from the Brazilian government and the payment of rent pressured managers to dismiss their employees.

Our study was performed while the fitness centers returned to their activities. Apparently, there was planning and articulation among managers, as some conducts were consensual, such as disinfecting the environment, availability of $70 \%$ alcohol and wearing masks. These measures are important and in line with WHO recommendations [6], but our main concern relates to the feasibility of social distancing. Managers acknowledge the importance of social distancing, but have divided opinions about vulnerable people. Approximately half of the sample believes that social distancing should be for specific age groups, known in Brazil as "vertical distancing". This method has been widespread in social media, but has no scientific evidence of its effectiveness. In addition, a mathematical model demonstrated that vertical distancing was equivalent to the control condition, where no action was taken to separate people [8].

The main transmission route of SARS-CoV-2 occurs through respiratory particles emitted mainly during speech [9]. Therefore, we do not recommend the practice of group classes where participants talk to each other. In our opinion, these classes should be held in outdoor environments, as evidence shows that the chances of outdoor infection are considerably lower compared to indoor environments [10]. Furthermore, we believe that the managers' proposed method of ensuring physical distance between users is insufficient. The floor markings do not prevent people from approaching, indicating that employees should take measures to ensure physical distance between users during exercise. We believe that temperature assessment, disinfection of environment, avoidance of crowding by scheduling, use of masks, and cross-ventilation tend to weaken the circulation of the virus, but may be insufficient to prevent infection by SARS-CoV-2. In this sense, recent studies find viral RNA in air samples, suggesting that infection can happen by aerosol $[11,12]$. Finally, the Brazilian state governments have begun to restrict the time available for exercise in fitness centers. This measure has no scientific support and tends to aggravate the practice of social distancing, as it induces crowding in the few hours available for training.

\section{Acknowledgements}

VNS is supported by Brazilian fellowship from Coordenação de Aperfeiçoamento de Pessoal de Nível Superior (CAPES) Processo n 88882.435438/2019-01.

\section{REFERENCE}

1. World Health Organization. Infection prevention and control during health care when COVID-19 is suspected: interim guidance [cited 2020 March]. Availabe from : < https://apps.who.int/iris/handle/10665/331495>.

2. Google. Covid-19: Community mobility reports [cited 2020] Availabe from : < https://www.google.com/covid19/ mobility/>.

3. Monetary International Fund [cited 2020]. Availabe from $:<$ https://pt.countryeconomy.com/paises/grupos/fmis.

4. Brazil. Decree No. 10,344 of 8 May 2020. Retrieved from http://www.planalto.gov.br/ccivil_03/_ato20192022/2020/Decreto/D10344.htm

5. Mohamed AA, Alawna Mand M. Role of increasing the aerobic capacity on improving the function of immune and respiratory systems in patients with coronavirus (COVID-19): A review. Diabetes Metab Syndr. 2020; 14(4):489-496. http://dx.doi.org/10.1016/j.dsx.2020.04.038

6. World Health Organization. Coronavirus disease 2019 (COVID-19): situation report 30 [cited 2020] Availabe from: <Retrieved from: https://www.who.int/emergencies/ diseases/novel-coronavirus-2019/situation-reports>.

7. Jang S, Han SH, Rhee JY. Cluster of Coronavirus Disease Associated with Fitness Dance Classes, South Korea. Emerg Infect Dis. 2020; 26(8):1917-1920. http://dx.doi. org/10.3201/eid2608.200633

8. Duczmal LH, Almeida ACL, Duczmal DB, Alves CRL, Magalhães FCO, Lima MS, et al. Vertical social distancing policy is ineffective to contain the COVID-19 pandemic. Cad Saude Publica. 2020; 36(5):e00084420. http://dx.doi. org/10.1590/0102-311×00084420 
9. World Health Organization. Modes of transmission of virus causing COVID-19: implications for IPC precaution recommendations: scientific brief [cited 2020 March]. Availabe from : < https://www.who.int/news-room/ commentaries/detail/modes-of-transmission-of-viruscausing-covid-19-implications-for-ipc-precautionrecommendations>.

10. Bulfone TC, Malekinejad M, Rutherford GW, Razani N. Outdoor Transmission of SARS-CoV-2 and Other Respiratory Viruses: A Systematic Review. J Infect Dis. 2021; 223(4):550-561. http://dx.doi.org/10.1093/infdis/jiaa742

11. Guo ZD, Wang ZY, Zhang SF, Li X, Li L, Li C, et al. Aerosol and Surface Distribution of Severe Acute Respiratory Syndrome Coronavirus 2 in Hospital Wards, Wuhan, China. Emerg Infect Dis. 2020; 26(7): 1583-1591. http://dx.doi. org/10.3201/eid2607.200885

12. Jiang $Y$, Wang $H$, Chen $Y$, He J, Chen $L$, Liu $Y$, et al. Clinical data on hospital environmental hygiene monitoring and medical staff protection during the coronavirus disease 2019 Outbreak. MedRxiv. 2020. http://dx.doi. org/10.1101/2020.02.25.20028043 